\title{
Corporate Social Responsibility, Multinational Corporations and the Law in Nigeria: Controlling Multinationals in Host States
}

\author{
Olufemi O Amao*
}

\begin{abstract}
There is a general perception that home jurisdictions in vulnerable areas are powerless when it comes to the control of multinational corporations. While this assertion is largely correct, this article argues that there cannot be effective control of multinational corporations ("'MNCs") at international, regional or private level without the corresponding development of an effective minimum institutional framework at the domestic level. This article examines the Nigerian legal framework for the regulation of MNCs with a view to underlining the weaknesses in the domestic forum, and also examines the prospects for enhancing the capacity of a domestic framework for the effective control of MNCs. The article argues that, while corporate social responsibility practice by MNCs is becoming well entrenched, this development cannot replace the need for effective host state regulation. The article focuses on company law and human rights law and suggests viable possibilities within the local context that may enhance the control of MNCs.
\end{abstract}

\section{INTRODUCTION: MULTINATIONAL CORPORATIONS AND CORPORATE SOCIAL RESPONSIBILITY IN NIGERIA}

Corporate social responsibility ("CSR") practices are most prominent in the oil and gas sector in Nigeria and among multinational corporations ("MNCs"). ${ }^{1}$ The major tools of CSR employed by MNCs in the country include corporate codes of conduct, voluntary social reporting and community development projects. The areas covered by CSR initiatives of MNCs include human rights, labour issues, transparency, bribery and corruption, employees' welfare, environmental issues, disclosure of information, and consumer protection. ${ }^{2}$ Most, if not all, of these areas are traditionally

* LLM, Warwick; LLM, Ibadan, Nigeria; LLB, Obafemi Awolowo University (formerly University of Ife), Nigeria; BA, Ilorin, Nigeria; BL, NLS, PhD Candidate, University College Cork, Ireland. Recipient of the President PhD scholarship and the Department of Law scholarship at University College, Cork (email: o.amao@student.ucc.ie).

1 U Idemudia and UE Ite "Corporate-community relations in Nigeria's oil industry: challenges and imperatives" (2006) 13 Corp Soc Responsib Environ Mgmt 194 at 195; K Amaeshi and others "Corporate social responsibility in Nigeria: western mimicry or indigenous influence" (2006) 24 Journal of Corporate Citizenship 83 at 84.

2 See for examples: Shell Nigeria Annual Report 2006 "People and the environment" available at: < http://www.shell.com/home/content/nigeria/news_and_library/ 
governed by positive law. It thus appears somehow inappropriate when CSR is conveniently described as going beyond the requirements of the law. ${ }^{3}$ The question then is why has CSR become so important for the operation of MNCs in Nigeria and why is the law taking a back seat? According to a report on Statoil, a Norwegian MNC in Nigeria: "Because of past and present experiences with petroleum activity in the Niger Delta, with widespread environmental destruction and little or no economic development, the population is deeply suspicious towards oil companies. Because of this, Statoil has to prove itself when it comes to corporate social responsibility in Nigeria."4

A closer look at the domestic forum (in this case Nigeria) would reveal that the gaps within domestic law, complimented by the absence of an enforceable international framework for controlling MNCs, have further amplified the importance of CSR. The strategic use of CSR is also true for other MNCs operating in Nigeria. However, commentators have been pointing out in recent times that the adoption of CSR as a strategy in Nigeria has failed to remove the suspicion and conflicts that exist between MNCs and other stakeholders. ${ }^{5}$

\section{BRIEF HISTORY OF MNCS IN NIGERIA}

The earliest MNCs entered the Nigerian jurisdiction during the colonial period under the British. It may therefore be instructive to note the trend of domestic law from this period in order to appreciate the dynamics of domestic regulations as regards MNCs. Nigeria is a former British colony and the British colonial administration established the basis of the modern Nigerian legal and institutional framework. One of the major aims of the British colonial administration was to make the colonies self sufficient and,

contd

publications/annual_reports_archive.html $>$ (last accessed 28 August 2007); Shell's "General business principle" available at: <http://www.shell.com/home/content/ nigeria/about_shell/how_we_work/principles/business_principles.html $>$ (last accessed 23 August 2007); Shell's "Approach to human rights" available at: <http://www. shell.com/home/content/nigeria/about_shell/issues/human_rights/hum_rights.html> (last accessed 23 August 2007); S Amadi, M Germiso and A Henriksen Statoil in Nigeria: Transparency and Local Content report no 1/2006 (2006, Framtiden, I vare hender) at 19; "The Chevron way" available at: <http://www.chevron.com/about/chevtex_way/ $>$ (last accessed 23 August 2007).

3 N Gunningham, R Kagan and D Thornton "Social licence and environmental protection: why businesses go beyond compliance" (2004) 29/2 Law \& Social Inquiry 307 at 308; C Parker "Meta-regulation: legal accountability for corporate social responsibility" in D McBarnet, A Voiculescu and T Campbell (eds) The New Corporate Accountability: Corporate Social Responsibility and the Law (2007, Cambridge University Press) at 207.

4 Amadi et al Statoil in Nigeria, above at note 2.

5 Idemudia and Ite "Corporate-community relations in Nigeria's oil industry", above at note 1 at 194 . 
at the same time, profitable. ${ }^{6}$ This aim influenced major decisions that were taken in the country, which would later impact on the operations of corporations in those early days. A significant early development was that in 1900 all mineral rights were nationalized and vested in the British crown and in 1907, contrary to widespread traditional practices of communal landholding, all lands were also nationalized and vested in the British crown. ${ }^{7}$

The policies of the colonial administration gave the pioneer British companies a free space in which to operate. The companies operated under a favourable legal regime because of their links to the colonial power which legislated for the country. ${ }^{8}$ During the colonial era and before the discovery of oil, the most important mineral resource produced in Nigeria was tin. ${ }^{9}$ To exploit this resource a British company, the Niger Company, set up the Naraguta Tin Mining Company under the charge of an engineer, HW Laws. In 1904, HW Laws led a military campaign on the location of the resource, the Jos Plateau, and took control of the area from indigenous people who were actively engaged in mining activities in the area. Though there was no official policy statement by the colonial government as to the displacement of indigenous people by the company, Lord Lugard, the head of the British administration in Nigeria stated that: "Minerals can only be discovered and exploited by the science and capital of Europeans, and to them the government can provide at once more security and more control than native chiefs and can allocate the royalties for the good of the country as a whole."10

\section{Colonial administration and the oil industry}

Oil prospecting started in Nigeria in $1906 .{ }^{11}$ However, no legislation was introduced to govern the oil industry until the end of 1914 with the introduction of the Oil Ordinance no 17. Under this law, oil exploration and exploitation was limited to British citizens and British companies. ${ }^{12}$ In

6 MS Steyn "Oil politics in Ecuador and Nigeria: a perspective from environmental history on the struggles between ethnics minority and national governments" (PhD thesis submitted to the Faculty of Humanities (Department of History) University of the Free State, Bloemfontein, South Africa 2003) at 74 and 147.

7 Id at 148

8 BO Nwabueze A Constitutional History of Nigeria (1982, C Hurst \& Co) at 35-37.

9 JH Morrison "Early tin production and Nigerian labour on the Jos Plateau 1906-21" (1977) 11/2 Canada Journal of African Studies 205 at 205.

10 Id at 208.

11 Steyn "Oil politics in Ecuador and Nigeria", above at note 6 at 180.

12 It has however been noted that this provision resulted in a paradox as the first company ever to undertake oil exploration in Nigeria (albeit unsuccessfully due to the First World War) was the German Bitumen Company. See PD Okonmah "Right to clean environment: the case for the people of oil-producing communities in Nigerian delta" (1997) 41/1 Journal of African Law 43 at 44; B Manby The Price of Oil: Corporate Responsibility and Human Rights Violations in Nigeria's Oil Producing Communities (1999, Human Rights Watch, New York) at 27; Y Omoregbe "The legal framework for the production of petroleum in Nigeria" (1987) 15 Journal of Energy and Natural Resources Law 273 at 274. 
1937, an exploration licence covering the whole mainland of Nigeria was granted to Shell-BP. ${ }^{13}$ The area covered was 357,000 square miles. The company was able to explore and select 15,000 square miles of the original concession without competition, thus securing a first mover advantage over later entrants. ${ }^{14}$ The company discovered oil in commercial quantity in 1958 in Oloibiri in the present Rivers State. ${ }^{15}$ By 1959, on the brink of Nigeria's independence, the sole-concessionary right granted to Shell-BP had been reviewed and companies of other western nationalities were brought into the field. Such companies include Mobil, Gulf, Agip, Safrap (now Elf), Tenneco and Amoseas (now Texaco and Chevron). ${ }^{16}$ Under the Petroleum Profits Tax Ordinance, introduced in 1959, an equal share of profit between the companies and the country was introduced for the first time.

\section{Legal developments after Nigeria's independence and the indigenization policy: a synopsis}

Nigeria became independent in 1960 and legislative changes were introduced that somewhat altered the status quo. Shell-BP for example, as indicated above, had to surrender some of its oil concessions and other MNCs were allowed into the field. ${ }^{17}$ Independence brought many more changes. Legislation was brought in to control some aspects of the operations of foreign companies including a number of major initiatives.

The Exchange Control Act of $1962^{18}$ set out the rules for investing nonresident capital in Nigerian businesses and defined methods for transferring foreign interests to non-residents and residents. Section 10(1)(a) of the act significantly restricted foreign exchange transactions in Nigeria by providing that: "No person shall, except with the permission of the Minister (a) transfer any security or create or transfer any interest in a security, to or in favour of a person resident outside Nigeria". The act thereby restricted the ability of foreigners, including corporations, to enter the Nigerian market. The act further restricted repatriation of foreign investment without the authorities' approval. Similarly the Nigerian Immigration Act of 1963 required a foreigner to obtain permission to set up or operate a limited liability company. ${ }^{19}$

A major development was the introduction by a military government in 1968 of the first local company law after independence. ${ }^{20}$ The Companies

13 Manby The Price of Oil, above at note 12 at 25.

14 JG Frynas, MP Beck and K Mellahi "Maintaining corporate dominance after decolonization: the 'first mover advantage' of Shell-BP in Nigeria" (2000) 27/85 Review of African Political Economy 407 at 407-09.

15 Ibid.

16 ibid.

17 B Onimode "Imperialism and multinational corporations: a case study of Nigeria" (1978) 9/2 Journal of Black Studies 207 at 210.

18 Cap 113, Laws of the Federation of Nigeria ("LFN") 1990.

19 Nigerian Immigration Act 1963, cap 171 LFN 1990.

20 The following civilian regime renamed it the Companies Act 1968. 
Act introduced the requirement for a foreign corporation to reincorporate as a Nigerian company before it could operate in Nigeria. This requirement is still part of Nigerian law. ${ }^{21}$ We shall return to the implications of this requirement later in this article. The rationale for this move must be viewed in the context of the importance attached to sovereignty by nascent states of the south at independence. ${ }^{22}$

\section{The Nigerian indigenization policy}

Like most other nascent nations at independence, Nigeria's perception of foreign MNCs was laden with distrust. The general belief was that MNCs, because of their close linkage with the past colonialists, might impede economic development. ${ }^{23}$ The country's leaders in the 1970 s thus perceived the process of indigenization as a way of asserting the nation's right under international law to exercise sovereignty over natural resources in her territory, to regulate foreign participation and exercise the right to naturalize such investments. ${ }^{24}$ After independence, successive governments were initially interested in nationalizing a limited sector of the Nigerian economy such as airlines, shipping and external communications. ${ }^{25}$ This arrangement still left a vast swathe of the Nigerian economy under the control of foreign MNCs. This selective attempt, however, did not deter the domination of the Nigerian economy by foreign MNCs.

The Nigerian government decided to adopt a more rigorous strategy in its second National Development Plan (1970-1974), which was to embark on partial and sometimes total nationalization of foreign controlled enterprises. ${ }^{26}$ However, when the enabling legislation was passed two years later (the Nigerian Enterprises Promotion Decree 1972), it proposed a gradual indigenization of the economy through the transfer of foreign holdings to indigenous people. ${ }^{27}$ It aimed to increase local participation but not eliminate foreign investment. The approach was not effective and the law was generally viewed as not achieving its aims. ${ }^{28} \mathrm{~A}$ second decree was enacted in 1977 (the Nigerian Enterprises Promotion Decree) which was largely similar to the earlier legislation but which increased government participation in some businesses, such as in the banking sector. ${ }^{29}$

21 Sec 54 Companies and Allied Matters Act, cap 59, LFN 1990.

22 TI Ogowewo "The shift to the classical theory of foreign investment: opening up the Nigerian market" (1995) 44/4 The International and Comparative Law Quarterly 915 at 916.

23 Ibid. See also V Akpotaire "The Nigerian indigenization laws as disincentives to foreign investments: the end of an era” (2005) 26/3 Business Law Review 62 at 62.

24 FC Beveridge "Taking control of foreign investment: a case study of indigenization in Nigeria” (1991) 40/2 The International and Comparative Law Quarterly 302 at 302-06.

25 Id at 307.

26 Ibid.

27 Ogowewo "The shift to the classical theory of foreign investment", above at note 22 at 925.

28 Id at 924-25.

29 This was followed by the Nigerian Enterprises (Issue of Non-voting Equity Shares) Act 1987. 
A paradigm shift came about in the 1980s with the emergence of economic liberalization, deregulation and the privatization of state owned corporations and interests. The Enterprises Promotion Act 1989 was introduced which repealed the Nigerian Enterprises Promotion Decree of 1977. The new act was Nigeria's first step towards the deregulation and liberalization of its economy. The act opened the field once again for 100 per cent foreign participation in most sectors of the Nigerian economy, subject to necessary approvals by the government. ${ }^{30}$ Since then, Nigeria has wholeheartedly embraced the neo liberal free market economy and has embarked on massive privatization and commercialization of the economy. ${ }^{31}$

\section{The Nigerian context today}

Today MNCs dominate major sectors of the Nigerian economy, including manufacturing, construction, petrochemicals and telecommunication. However their impact is most felt in the oil production and extraction industry. Nigeria is currently the largest producer of crude petroleum in Africa, the fifth largest producer within the Organization of the Petroleum Exporting Countries ("OPEC") and the eighth largest exporter of crude oil in the world. Today Nigeria earns over 95 per cent of its export revenue from the oil and gas sector, accounting for over 40 per cent of gross domestic product. $^{32}$ The major MNCs in today's Nigeria include the Anglo-Dutch Royal Shell ("Shell"), ${ }^{33}$ which is the largest oil producer in Nigeria producing more than 40 per cent of Nigeria's total output. There are also the United States domiciled corporations, Exxon-Mobil and Chevron/Texaco, which produce about 38 per cent of Nigeria's output. Other US corporations in Nigeria are Ashland, Sun Oil and Conoco. In addition there are France's Total, Italy's Agip International, Norway's Statoil and South Africa's Sasol.

All the foreign MNCs in the oil and gas sector operate in joint venture partnership with the Nigerian National Petroleum Corporation ("NNPC"), a statutorily established, state-owned corporation. A closer look at the structure of a typical MNC would reveal the following: a parent company in Europe or the United States; and subsidiaries incorporated as Nigerian corporations which engage in joint venture partnerships with the federal government of Nigeria through the NNPC, typically in a ratio of 55-60 per cent to the government and 40-45 per cent to the corporation. The shareholders of the parent company are usually in the countries of the north, usually the United States and Europe. ${ }^{34}$ The MNC maintains managerial control of the enterprise. The government contributes

30 Akpotaire "The Nigerian indigenization laws", above at note 23 at 66.

31 Public Enterprises (Privatization and Commercialization) Act 1999.

32 Manby The Price of Oil, above at note 12 at 6-10.

33 Primarily listed on the London Stock Exchange and the Amsterdam Stock Exchange.

34 For example, the Exxon Mobil subsidiary is owned by NNPC (60\%) and Mobil Oil (40\%). Shell Petroleum Development Corporation's shareholding structure comprises NNPC (55\%), Shell International (30\%), Elf Petroleum (10\%) and Agip Oil (5\%). Chevron 
proportionately to the cost of carrying out the oil operations and receives a share of the production in the same proportion.

\section{NIGERIAN LAW AND THE CONTROL OF MNCs}

There are several areas of Nigerian law that impact on the operations of MNCs in varying degrees. These include company law, human rights law, criminal law, tort law, labour law and anti-corruption laws. Several cases have been brought under domestic tort law with very limited success because of inherent procedural problems. ${ }^{35}$ Other areas of Nigerian law have been less explored in this respect. This article posits that there are potential developments in Nigerian company law and human rights law which may prove more effective in the control of MNCs. Domestic company law is a major way in which a state controls corporations, both local and foreign, within its jurisdiction. This is because company law gives life to the company, specifies its working parameters and also specifies the circumstances in which a company may end the life given to it under the law. ${ }^{36}$ This article therefore considers in the following sections the extent to which provisions of Nigerian company law have impacted on MNCs and the implications of Nigerian company law for the control of MNCs.

\section{A brief history of Nigerian company law}

The abolition of the slave trade and the formal establishment of British authority over its Nigerian colony saw a rapid growth in both internal and external trade in 19th century Nigeria. ${ }^{37}$ The early companies in Nigeria were British based. By virtue of colonial statutes enacted between 1876 and 1922, the laws applicable to companies in Nigeria at this time were the "common law, the doctrines of equity, and the statutes of general application in England on the first day of January, 1900" subject to any later relevant statute. ${ }^{38}$ The implication of this approach was that common law concepts, such as the concept of the separate and independent legal personality of companies as enunciated in Salomon $v$ Salomon, ${ }^{39}$ were

contd

Nigeria Limited is owned by NNPC (60\%) and Chevron Texaco (40\%). Nigeria Agip Oil Company is owned by NNPC (60\%), Agip Oil (20\%) and Phillips Petroleum (20\%). Elf Nigeria Ltd is owned by the NNPC (60\%) and TotalElfFina $(40 \%)$. Texaco Overseas (Nigeria) Petroleum Company is owned by the NNPC (60\%), Chevron (20\%) and Texaco (20\%). See <http://www.nnpcgroup.com/jvoperation.htm $>$ (last accessed 6 June 2007).

35 JG Frynas "Legal change in Africa: evidence from oil-related litigation in Nigeria" (1999) 43/2 Journal of African Law 121 at 122-23.

36 NHD Foster and J Ball "Imperialism and accountability in corporate law: the limitations of incorporation as a regulatory mechanism" in S Macleod (ed) Global Governance and the Quest for Justice: Corporate Governance (2006, Hart Publishing, Oxford) 93 at $93-96$.

37 JO Orojo Company Law in Nigeria (3rd ed, 1992, Mbeyi \& Associates, Lagos) at 1.

38 Id at 17-18.

39 [1897] AC 22. 
received into Nigerian company law and have since remained part of the law. ${ }^{40}$ However, with the continued growth of trade, the colonialists felt it necessary to promulgate laws to facilitate business activities locally. The first company law in Nigeria was the Companies Ordinance of 1912, which was a local enactment of the English Companies (Consolidation) Act 1908. Later versions of Nigerian company law were also modelled on the laws in England. Nigeria's current company law (now known as the Companies and Allied Matters Act 1990 ("CAMA")) is largely modelled on the British Companies Act 1948. ${ }^{41}$

\section{MNCs and national companies: a clarification of terms}

It is important to note the difference between an MNC as an entity and a company incorporated under domestic company law. Kamminga described an MNC as "a legal person that owns or controls production, distribution or service, facilities outside the country it is based." 42 According to Jagers: "The common feature of these large and often rather opaque corporations is that they operate across national borders. Operating in many different countries places these corporations outside the effective supervision of domestic and international law, which can result in a deficiency."43

In Dine's view, "multinational and transnational companies do not exist as an entity defined or recognized by law. They are made up of complex structures of individual companies with an enormous variety of interrelationships." 44 An incorporated company under domestic law is, however, an abstract concept, which is an invention of the domestic law. While individual companies incorporated under the law are strictly subject to the law under which they are incorporated, the MNC is made up of a network of corporations, which are incorporated in different jurisdictions, and it carries on business across different jurisdictions. The consequence of the multi jurisdictional nature of MNCs is that the ability of a host jurisdiction to control MNCs is limited to their manifest presence within that host jurisdiction. In most cases in Nigeria, the presence of an MNC is manifested by the establishment of a subsidiary of the company under Nigerian law, to operate on behalf of the parent company.

\footnotetext{
40 Orojo Company Law in Nigeria, above at note 37 at 17-18.

41 A Guobadia "Protecting minority and public interests in Nigerian company law: the corporate affairs commission as a corporations ombudsman" in F McMillan (ed) International Company Law Annual vol 1 (2000, Hart Publishing) 81 at 81-83.

42 MT Kamminga "Holding multinational corporations accountable for human rights abuses: a challenge for the EC" in P Alston (ed) The EU and Human Rights (1999, Oxford University Press) 553 at 554.

43 N Jagers Corporate Human Rights Obligations: In Search of Accountability (2002, Intersentia) at 11.

44 J Dine Companies, International Trade and Human Rights (2005, Cambridge University Press) at 48.
} 


\title{
Local incorporation as a strategy for control
}

As stated earlier, the first measure aimed at controlling MNCs directly was introduced by the Nigerian Companies Act 1968. The act introduced the requirement of local incorporation with the aim of bringing MNCs under the ambit of Nigerian company law and making them comply with requirements under the act such as disclosure of accounts, and regulation of directors and shareholders. This provision remains part of Nigerian company law. Section 54 of the CAMA provides:

\begin{abstract}
"Subject to sections 56 to 59 of this Decree every foreign company which before or after the commencement of this Decree was incorporated outside Nigeria, and having the intention of carrying on business in Nigeria shall take all steps necessary to obtain incorporation as a separate entity in Nigeria for that purpose, but until so incorporated, the foreign company shall not carry on business in Nigeria or exercise any of the powers of a registered company and shall not have a place of business or an address for service of documents or processes in Nigeria for any purpose other than the receipt of notices and other documents, as matters preliminary to incorporation under this Decree."
\end{abstract}

It must be observed that this provision is unique to Nigerian company law as English company law (which was the model for the Nigerian law) has no such provision. In England, a foreign company is not required to reincorporate but must file the names and addresses of the persons authorized to accept service on its behalf with the registrar of companies. ${ }^{45}$ Ogowewo has challenged the utility of this requirement which, according to him, only has symbolic value and constitutes an unnecessary restriction on foreign investment. ${ }^{46} \mathrm{~A}$ worrisome aspect of the provision in the context of this article is that it makes it easier for the parent companies of MNC subsidiaries in Nigeria to deny liability for any adverse consequence of the operations of their subsidiary, since the subsidiary is incorporated and legally recognized as a Nigerian company. This argument was canvassed in a suit brought by a community in the oil producing area against Mobil and its parent company in the US. ${ }^{47}$ Another implication of this legislation is that it may impede the ability of Nigerians seeking redress from MNCs to approach the home jurisdiction of the parent companies.

The exact rationale for retaining this legislation in Nigerian law is unclear. This is more so because foreign companies are subject to the Nigerian jurisdiction by the fact that they are doing business in Nigeria and

45 See sec 691 of Companies Act 1985.

46 Ogowewo "The shift to the classical theory of foreign investment", above at note 22 at 925.

47 Mobil Producing (Nig) United v Monokpo (2003) 18 NWLR (Pt 852) 346 at 401. This distinction was also employed by the Court of Appeal in granting an oil community a stay of execution of a judgment against Shell for gas flaring in Shell Petroleum Development Company (SPDC) of Nigeria $v$ Dr Pere Ajuwa and Honourable Ingo Mac-Etteli Court of Appeal, Abuja division, no CA/A/209/06, 27 May 2007. 
not just because they are incorporated in Nigeria. This is in line with practices in other common law jurisdictions. ${ }^{48}$ Furthermore, section 60 of the CAMA allows foreign companies to sue and be sued in Nigeria in their name or the name of their agents. The Nigerian courts have held that a company incorporated other than in Nigeria can bring an action in the Nigerian courts. ${ }^{49}$ The section is therefore an unnecessary provision which is counterproductive.

\section{Groups of companies under Nigerian law}

The next issue to examine is the approach of Nigerian company law to groups of companies and to see whether this has any impact on the operations of MNCs. The main question here is whether an MNC can be held liable for the acts of its subsidiary under Nigerian law. The default rule in Nigeria, as in other common law jurisdictions, is that a holding company and its subsidiaries are each distinct and separate legal persons. ${ }^{50}$ It is also the position of Nigerian law that a subsidiary is not an agent of the parent company but a different entity. ${ }^{51}$ However, theoretically it may be possible to proceed against the parent company of an MNC under Nigerian law in very limited circumstances, but the problem with this possibility is the difficulty in enforcing any judgment obtained. As stated earlier, a foreign company, regardless of whether or not it is incorporated in Nigeria, can sue and be sued in the Nigerian courts if it does business in Nigeria. Secondly, Nigerian company law recognizes the relationship between holding, subsidiary and wholly-owned subsidiary companies. According to section 338 of the CAMA, a company is deemed to be a holding company of another if the company is its subsidiary 52 and a company is deemed to be a subsidiary of another if that other company is a member of it and controls the composition of its board of directors or holds more than half of its nominal equity share capital or if the other company is a subsidiary of any company which is that other's subsidiary. ${ }^{53}$ The CAMA further provides that a body corporate is deemed to be the wholly owned subsidiary of another if

48 Okura \& Co Ltd v Forsbacka Jernverks Aktiebolag (1914) 1 KB 715. See also Offshore International SA $v$ Federal Board of Inland Revenue (1976) 1NTC 385, where a Nigerian court held that a company incorporated in Panama, having its principal office in Texas and no place of business in Nigeria, was liable to pay tax for the operation of its business carried out through a subsidiary in Nigeria under the Nigerian Companies Income Tax Act.

See Kitchen Equip (WA) Ltd $v$ Staines Catering Equip International Ltd suit no FCA/L/17182 OF 28/2/83; Nigerian Bank for Commerce and Industry $v$ Europa Traders (UK) Ltd (1990) 6 NWLR 36, 41 CA; Ishola v Societe Generale Bank (Nig) Ltd (1997) 2 NWLR (pt 488) 406 SC; UBN Plc v Jase Motors (Nig) Ltd (1997) 7 NWLR (pt 513) 387 CA; Watanmal (Singapore) $v$ Liz Olofin ECo (1998) 1 NWLR (pt 533) 311 CA; Ritz E Co KG v Techno Ltd (1999) 4 NWLR (pt 598) 298 CA; Saeby v Olaogun (2001) 11 WRN 179 SC.

50 MO Kanu E Sons $v$ FBN Plc (1998) 11 NWLR (pt 572) 116 at 121.

51 Musa $v$ Ehidiamhen (1994) 3 NWLR (pt 334) 554 CA.

52 Sec 338(5) CAMA.

53 Sec 338(1)(a) and (b) CAMA. 
it has no member except that other's wholly owned subsidiaries and its or their nominees. ${ }^{54}$

Under the CAMA, the veil of incorporation of the subsidiary may be lifted to reach the holding company in certain circumstances. The veil may be lifted in order to ensure compliance with the requirement to prepare financial statements, where a group of companies is virtually a partnership and where one company is a trustee of another. ${ }^{55}$ Furthermore, the veil may be lifted where the Corporate Affairs Commission (established under section 1 of the CAMA) is investigating the affairs of a company under section 316, or where a company is acting as an agent of shareholders or is created as a sham. ${ }^{56}$ The court is also empowered to disregard the legal personality of a subsidiary in appropriate cases in the interests of justice. The last ground is wide and could accommodate a variety of issues.

However, the limitation in lifting the veil of the subsidiary of an MNC to reach the holding company has been pointed out by the leading authority on Nigerian company law, Orojo. He noted that the fact that a Nigerian company has a wholly owned subsidiary in a foreign country would not make the Nigerian parent company subject to the jurisdiction of that foreign country, and that, if the foreign country gives judgment against the Nigerian parent company, the Nigerian courts would refuse to enforce it. ${ }^{57}$ It is opined that other jurisdictions would take similar approaches to any attempt by a Nigerian court to reach the parent company of a Nigerian subsidiary based abroad. According to Dine, a subsidiary is more than likely to be viewed as a separate entity in the host state in the unlikely event that the veil is lifted and the parent company found liable, making it difficult to enforce any judgment obtained in a foreign country. ${ }^{58}$

\section{Mandatory disclosure requirements under company law and MNCs in Nigeria}

Mandatory disclosure requirements present an important strategy by which the law is being employed to promote CSR. The debates on corporate governance since the 1990s have led to a wider range of disclosures beyond the financial situation of the company. Disclosure regimes are gradually, if slowly, changing to reflect these developments in business activities. Villiers however argued in her book, which is an overview of the system of corporate reporting in company law, that problems exist in the disclosure regime, partly because it fails to keep pace with the speed of changes in business activities and partly because its character is shaped by the

54 Sec 338(5)(b) CAMA.

55 See sec 345 CAMA; see also DHN Food Distributors Ltd $v$ London Borough of Tower Hamlets (1976) 3 All ER 462.

56 See Public Finance Securities Ltd $v$ Jefia (1998) 3 NWLR (pt 543) 602, 604 CA.

57 Orojo Company Law in Nigeria, above at note 37 at 85.

58 Dine Companies, International Trade and Human Rights, above at note 44 at 49. 
traditional shareholder-centred legal model of the company. ${ }^{59}$ She argued that:

"The corporate reporting and disclosure system is closely tied to the profit maximization goal of shareholders and therefore focuses primarily on financial accounting and reporting. This narrow focus influences developments relating to social and environmental reporting so that stakeholder advocates are likely to be disappointed if they rely on the disclosure system in its present form to take their objectives forward." 60

In the UK for example, the new business review requirement in the directors' report which replaced the erstwhile operating and financial review and directors' report legislation, ${ }^{61}$ though not as comprehensive as the earlier legislation, requires directors of businesses other than small businesses to report on non-financial matters such as environmental and employee issues. Any company which fails to comply with the requirement will be liable to civil penalties. Furthermore, the financial reporting review panel (under the financial reporting council) is legally empowered to review company directors' reports and may go to court if necessary to compel a company to revise its report. ${ }^{62}$ France also amended her laws in 2001 to require extensive disclosure of social and environmental issues by corporations. Notably article 116 of the New Economic Regulation of France made it mandatory for all companies traded on the French Stock Exchange to employ "triple-bottom-line" reporting. The article requires companies to give detailed reports on environmental, labour, community involvement, and health and safety information in its annual report.

\section{Disclosure requirements under Nigerian law}

Despite the overarching importance of promoting corporate responsibility in the Nigerian environment, little attention has been paid to utilizing social reporting as a means of promoting the responsibility of corporations in the country. Prior to 1968 , there was no provision for mandatory reporting of any form under Nigerian company law. The 1968 Companies Act introduced the concept of mandatory reporting which was modelled on the disclosure provisions in the British Companies Act 1948. The scope of the disclosure requirements under the act has been expanded under the current CAMA. Section 331 of the CAMA requires every company to keep accounting records sufficient to show and explain the transactions of the company. In addition it must disclose with reasonable accuracy the financial position of the company. The record must contain entries from

59 C Villiers Corporate Reporting and Company Law (2006, Cambridge University Press) at xi.

60 Id at xii.

61 SI 2005/1011 The Companies Act (Operating and Financial review and Directors' Report etc) Regulation 2005.

62 'Guidance on the changes to the directors' report requirements in the Companies Act 1985” availableat: < http://www.dti.gov.uk/files/file28384.doc $>$ (lastaccessed 12 July 2006). 
day to day of all monies received and expended by the company and matters in which such transactions were made. It must also contain a record of the assets and the liabilities of the company. The records are required to be kept in the registered office of the company or other places in Nigeria as the directors may think fit and should at all times be open to inspection by the officers of the company. ${ }^{63}$

Section 334 of the CAMA mandates the company's directors to prepare a financial statement in respect of each financial year. The information required to be disclosed includes:
a) statement of the accounting policies
b) the balance sheet as at the last day of the financial year
c) a profit and loss account or, in the case of a company not trading for profit, an income and expenditure account for the financial year
d) notes on the accounts
e) the auditor's report
f) the directors' report
g) a statement of the source and application of funds
h) a value added statement for the financial year
i) a five-year financial summary
j) in the case of a holding company, the group financial statement. ${ }^{64}$

An interesting aspect of the requirements is the provision in $(\mathrm{h})$ that the statement should include "a value added statement for the financial year". The leading authority on Nigerian company law described this as "a requirement to report the wealth created by company during the financial year and its distribution among various interest groups such as the employees, governments, creditors, proprietors and the company". ${ }^{65}$ The provision is thus tied to financial reporting. The only exceptions under the act are three heads of information relating to the employment of disabled persons, health, safety and welfare at work of the company's employees, and employees' involvement and training; these must be included in the annual report. ${ }^{66}$ These requirements are however too narrow to encompass the disclosure requirements envisaged in the CSR debate. Reporting requirements under the current law in Nigeria are largely fixated on financial reporting, do not accommodate issues raised within the CSR debate, and have not followed developments in other parts of the world.

The discussion so far has shown that, despite the potential of domestic company law as a tool for controlling MNCs, Nigerian company law has failed to rise to the challenge. While inhibiting in one respect the ability to reach the parent companies of MNCs, Nigerian company law also failed to develop to meet modern realities in companies' operations. Considering

\footnotetext{
63 Sec 332(1) CAMA.

64 Sec 344(2) CAMA.

65 Orojo Company Law in Nigeria, above at note 37 at 378.

66 Sec 342 CAMA.
} 
the importance of CSR and the control of MNCs within the Nigerian context, it is rather surprising that there has been no significant attempt to utilize the potential of company law in this respect. A significant development that underscores the unresponsiveness of the Nigerian corporate law regime to these challenges is the lacunae in the code of corporate governance introduced in Nigeria in 2003. While other African countries that introduced code of corporate governance in the last decade have followed an inclusive model of corporate governance that incorporates other stakeholder issues in varying degrees, the Nigerian code of corporate governance is a notable exception, retaining the traditional shareholder- centric model of corporate governance. ${ }^{67}$

While Nigerian company law has largely been ineffective in the face of the challenges posed by MNCs, some recent developments in the area of human rights law hold out viable possibilities. The next part of this article discusses these developments. Later, the article proffers some suggestions for law reform in Nigeria.

\section{MNCS AND HUMAN RIGHTS IN NIGERIA}

The question of the extent of the violation of human rights by MNCs in Nigeria has been the subject of considerable debate. The reason for this is that, because of the paucity of legal mechanisms for ventilating human rights abuse complaints against MNCS, many of the issues remain at the level of allegations by citizens and civil society organizations, both local and international. Of note, however, are cases brought in respect of MNCs' human right abuses under the Alien Torts Act in the US and the African Commission on Human and Peoples' Rights. ${ }^{68}$ There is however a general consensus among writers on the subject that there are important issues implicating human rights violations emanating from the operations of MNCs in Nigeria. ${ }^{69}$ It would be pertinent to start this part of the article with a synopsis of the human rights sphere in the country.

67 GJ Rossouw "Business ethics and corporate governance in Africa” (2005) 44 Business $\mathcal{E}$ Society 94 at 97.

68 See for examples Wiwa $v$ Royal Dutch Petroleum Company 226 F.3d 88 (2d cir 2000), 532 US 941 (2001); Bowoto $v$ Chevron Texaco Corp, 312 F supp 2d 1229; and Social and Economic Rights Action Centre ("SERAC") and The Centre for Economic and Social Rights v Nigeria (2001), communication no 155/96, (African Commission on Human and Peoples' Rights), online: University of Minnesota Human Rights Library, available at: < http://www1.umn. edu/humanrts/africa/comcases/155-96b.html> (last accessed 29 August 2007).

69 See FM Edoho “Oil transnational corporations: corporate responsibility and environmental sustainability” (2007) Corp Soc Responsib Environ Mgmt (forthcoming); R Boele, H Fabig and D Wheeler "Shell, Nigeria and the Ogoni. A study in unsustainable development: 1 . The story of Shell, Nigeria and the Ogoni people - environment, economy, relationships: conflict and prospects for resolution" (2001) 9 Sustainable Development 74 at 74-86; R Boele, H Fabig and D Wheeler "Shell, Nigeria and the Ogoni. A study in unsustainable development: II. Corporate social responsibility and environmental management and stakeholder management versus a right-based approach to sustainable development" (2001) 9 Sustainable Development at 39 at 39-48; Manby The Price 


\section{The human rights sphere under Nigerian law}

Since independence, Nigeria has included provisions on human rights in its constitution. The first set of fundamental rights and basic freedom provisions were introduced into the Nigerian constitution on the advice of the Willink Commission set up by the British colonial administration to consider the position of minority groups in relation to majority groups after independence. ${ }^{70}$ The original agitation of the minorities was for the creation of separate states for them. However the Willink Commission recommended the inclusion of fundamental rights provisions in the Nigerian constitution as an effective way of dealing with minority issues. ${ }^{71}$ The Nigerian Independence Constitution of 1960 therefore contained provisions on human rights, which have featured in all subsequent constitutions. It must be observed that the constitutional provisions were suspended under the various military governments that intervened in Nigeria's governance at various times in the past, hindering the promotion and protection of human rights.

The constitutions before 1979 concentrated on natural rights, ie inalienable rights including rights to life and pursuit of happiness, freedom of speech, freedom of association and equality before the law. Little attention was paid to civil and political rights, while economic, political and social rights were largely ignored. ${ }^{72}$ The 1979 constitution, introduced to usher in a new democratic dispensation, widened the scope of rights. Substantive rights were widened to include the rights to life, dignity of the human person, personal liberty, private and family life, freedom of expression, press, peaceful assembly and association, freedom from discrimination, and ownership of property. ${ }^{73}$ The constitution also contained procedural rights, including the rights to habeas corpus, public hearing, counsel of choice, and information in an arrest or detention, the presumption of innocence in criminal trials, and protection from ex post facto laws, double jeopardy and self incrimination. Lastly the constitution prevented the government from acquiring any private property without prompt payment of compensation. Furthermore it placed a duty on the government to provide opportunities to any person claiming such compensation (including a right of access for the determination of his interest in the property and determination of the compensation payable) in a court of law, tribunal or other body having jurisdiction. ${ }^{74}$

contd

of Oil, above at note 12; H Fabig "The Body Shop and the Ogoni” in M Addo (ed) Human Rights Standards and the Responsibility of Transnational Corporations (1999, Kluwer, The Hague) 309 at 309-21; and MJ Watts "Righteous oil? Human rights, the oil complex, and corporate social responsibility” (2005) 30 Annu Rev Environ Resour 373 at 373 and 387.

70 Manby, The Price of Oil, above at note 12 at 4.

71 M Akpan "The 1979 Nigerian constitution and human rights" (1980) 2/2 Universal Human Rights 23 at 27-28.

72 Ibid.

73 Chap IV of the Nigerian constitution 1999.

74 Sec 40(1) Nigerian constitution 1999. 
The 1979 constitution introduced into Nigeria for the first time certain political, social, educational and economic rights. These rights were contained in chapter II of the constitution under the heading "Fundamental objectives and directives of principles of state policy". However, by virtue of section $6(6)(c)$ these rights were non-justiciable, a position confirmed by the courts for over three decades after the introduction of the rights. ${ }^{75}$ Section 15 of the constitution placed an obligation on the government to: provide adequate facilities to encourage free mobility of people, goods and services; secure residence rights for every citizen; encourage intermarriage among various groups; and promote or encourage the formation of associations that cut across ethnic, linguistic or other social barriers. Section 17 covered social rights, including: the right of equality, obligations and opportunities before the law; the duty of government to act humanely; the independence, impartiality, integrity of and easy accessibility to the courts of law; the opportunity to secure adequate means of livelihood and to secure suitable employment; just and humane conditions of work and adequate facilities for leisure and for social, religious and cultural life; safeguards as to health and safety in the workplace; adequate medical and health facilities for all persons; the right to equal pay for equal work; protection of children, young persons and the aged, and provision of public assistance in case of need. Section 18 covered educational rights and the rights and responsibility of government to eradicate illiteracy by providing (when practicable) free, compulsory and universal primary education, free secondary education, free university education, and free adult literacy programmes.

It must be observed on a general note that section 41 of the 1979 constitution allowed the government to derogate from the provided rights, in the interests of defence, public safety, public order, public morality, public health or for the purpose of protecting the right and freedom of other persons. The High Courts in Nigeria are vested with the responsibility of adjudicating on the enforcement of the human rights provisions in the constitution. Though the 1979 constitution was replaced in 1999 with the 1999 constitution, the provisions in respect of human rights have remained the same.

An interesting development occurred in 2002 when the Supreme Court of Nigeria ruled, for the first time, that the rights contained in chapter II of the constitution (fundamental objectives and directives of principles of state policy) may be enforceable in certain circumstances and also against private persons. In Attorney General of Ondo State $v$ Attorney General of the Federation and 35 Others, ${ }^{76}$ one of the issues that the Supreme Court had to determine was whether a law made by the National Assembly pursuant to sections 13 and $15(5)^{77}$ (which are under the non-justiciable provisions of

75 See for example Okojie v AG Lagos State (1981) 2 NCLR 337.

76 [2002] 6 SC (pt 1) at 1.

77 The sections provide: 13: "It shall be the duty and responsibility of all organs of government, and of all authorities and persons, exercising legislative, executive or 
the constitution) is beyond the powers of parliament and therefore unenforceable. The court also considered whether the law can be enforced against a private person as the law purported to do. The National Assembly had enacted the Anti Corruption Bill pursuant to the stated sections in order to deal with the prevalent issues of corruption in Nigeria. The Supreme Court observed:

"It has been argued that the Fundamental Objectives and the Directive Principles of State Policy are meant for authorities that exercise legislative, executive and judicial powers only and therefore any enactment to enforce their observance can apply only to such persons in authority and should not be extended to private persons, companies or private organizations. This may well be so, if narrow interpretation is to be given to the provisions, but it must be remembered that we are here concerned not with the interpretation of a statute but the Constitution which is our organic law or grundnorm. Any narrow interpretation of its provisions will do violence to it and will fail to achieve the goal set by the Constitution. Corruption is not a disease which afflicts public officers alone but society as a whole. If it is therefore to be eradicated effectively, the solution to it must be pervasive to cover every segment of the society." (Emphasis added)

The court went on to hold that, even though the provisions of the chapter are unenforceable, the National Assembly has the power to legislate on the provisions and make them enforceable against government bodies and private persons. According to the court, item 60(a) of the exclusive legislative list of part 1 of the second schedule to the Nigerian constitution empowers the National Assembly to legislate for the federation or any part of it for the purpose of promoting and enforcing the observation of the fundamental objective and directive principles contained in chapter II. Therefore, any step taken by the National Assembly in the furtherance of the above is valid and enforceable in the court. Therefore, these provisions may potentially be more potent than was earlier thought.

It is significant to note that a similar approach was taken by the South African court in respect of section 7(2) of the constitution of South Africa which requires the state to respect, promote and fulfil the rights in the Bill of Rights. The court held that the section applied also to provisions that are considered non- justiciable. According to the court, "given that socioeconomic rights are expressly included in the Bill, the question is not whether they are justiciable, but how to enforce them in a given case". ${ }^{78}$

contd

judicial powers, to conform to, observe and apply the provisions of this constitution". 15(5): "The State shall abolish all corrupt practices and abuse of power".

78 Grootboom \& Ors $v$ Oostenberg Municipality \& Ors CCT 11/00, 4 October 2000; Grootboom v Oostenberg Municipality \& Ors CCT38/00 (2000). See also Port Elizabeth Municipality $v$ Various Occupiers CCT53/03 (2004); Minister of Health $v$ Treatment Action Campaign CCT8/02 (2002); and Khosa and Ors v Minister of Social Development CCT13/03 (2003). 
The courts in South Africa have, therefore, enforced socio-economic rights, such as the right under the South African constitution of homeless children to shelter.

\section{Nigeria and international human rights law}

Apart from domestic human rights provisions, Nigeria has ratified nine out of the 13 core international human rights treaties in force today. These include the International Convention on the Elimination of All Forms of Racial Discrimination (1969), International Covenant on Civil and Political Rights (1993), International Covenant on Economic, Social and Cultural Rights (1993), Convention on the Elimination of all Forms of Discrimination against Women (1985), Convention against Torture and Other Cruel, Inhuman and Degrading Treatment or Punishment (2001), Convention on the Rights of the Child (1991), Optional Protocol to the Convention on the Rights of the Child on the involvement of Children in Armed Conflict (2000) and Optional Protocol to the Convention on the Rights of the Child on the Sale of Children, Child Prostitution and Child Pornography (2000).

Furthermore, Nigeria has ratified the African Charter on Human and Peoples' Rights (the "African Charter") 79 and subsequently incorporated it into domestic law through the African Charter on Human and Peoples' Rights (Ratification and Enforcement) Decree. ${ }^{80}$ The provisions of the African Charter have been held to be part of Nigerian domestic law, ${ }^{81}$ which can be enforced through the procedure provided under the Nigerian constitution. ${ }^{82}$

In Abacha $v$ Fawehinmi ${ }^{83}$ the Nigerian Supreme Court had the opportunity to clarify the status of the African Charter under Nigerian law. In that case, Gani Fawehinmi, a human rights activist and lawyer in the country had been arrested and detained for a week without being presented with an arrest warrant or given reasons for his arrest. He was held in total isolation before being transferred to another prison. Fawehinmi challenged the detention on the ground that it violated his fundamental rights under Articles 4, 5, 6 and 12(3) of the African Charter. The Supreme Court held that, since the African Charter had been incorporated into Nigerian domestic legal system, it was a statute with international flavour. Therefore if there is a conflict between it and another domestic statute, its provisions will prevail over those other statutes, because it is presumed that the legislature does not intend to breach an international obligation. It was held that the African Charter possesses a "greater vigour and strength than any other domestic statute".

79 (1981) 21 ILM 58.

80 Cap 10 vol 1 LFN 1990.

81 Garba $v$ Lagos State Attorney General Suit ID/599m/91 and Agbakoba v Director State Security Services (1994) 6 NWLR 475.

82 Nemi $v$ The State (1994) 1 LRC 376 (Nigeria, SC). See also F Viljoen "Application of the African Charter on Human and Peoples' Rights by domestic courts in Africa” (1999) 43 Journal of African Law 1-17. 


\title{
Controlling MNCs through human right provisions: the case of Gbemre $v$ Shell and Two Others ("Gbemre v Shell") 84
}

A development that signalled the possibility of using human rights provisions for the purpose of controlling MNCs in Nigeria came with the decision in Gbemre $v$ Shell. Before delving into the decision, it would be pertinent to highlight the background to the case.

\section{Background}

More gas is flared in Nigeria than anywhere else in the world. ${ }^{85}$ Oil companies flare gas because they found it more profitable to do so where oil deposits are mixed with gas. ${ }^{86}$ Gas flaring causes pollution in the local environment affecting humans, animals and vegetation and has also been said to contribute to climate change. ${ }^{87}$ According to a report:

\begin{abstract}
"The air pollution stems firstly from the sheer quantities of hydrocarbons being burnt off, but also because the gas being burnt is not only natural gas (mostly methane), but also heavier gas types and pollutants like hydrogen sulphide (H2S), which give off more air pollution. In addition to nitrogen and sulphur oxides (which cause respiratory problems and acid rain) and unburnt methane26, the flaring also gives off cancer inducing benzene and other toxic gases. In addition you have $\mathrm{CO}_{2}$, which is not a big local problem, but should worry the global community, and indeed Africa and Nigeria, which can be hit pretty hard by global warming. The $\mathrm{CO}_{2}$ emissions from flaring in Nigeria were estimated at 34 million tons for the year 2002." 88
\end{abstract}

It has been reported that local people exposed to gas flaring complained of respiratory problems such as asthma and bronchitis and other ailments such as cancer, leading to premature death. ${ }^{89}$ It has also been alleged that gas flaring contributes to acid rain which corrodes villagers' buildings. Local people also complained of intense heat and roaring noise emanating from gas flaring..$^{90}$ This practice of flaring gas is in contrast to practice in the western world where associated gas is used or re-injected into the

84 Jonah Gbemre $v$ Shell Petroleum Development Corporation of Nigeria Ltd and Ors (suit no FHC/ B/CS/53/05, Federal High Court, Benin Judicial Divison, 14 November 2005).

85 Friends of the Earth press release: "Shell fails to obey gas flaring order" (2007) available at: < http://www.foe.co.uk/> (last accessed 14 August 2007); Okonmah "Right to clean environment", above at note 12 at 51.

86 Omoregbe "The legal framework for the production of petroleum in Nigeria", above at note 12 at 284 .

87 Ibid.

88 Amadi et al Statoil in Nigeria, above at note 2 at 19.

89 Friends of the Earth media briefing "Gas flaring in Nigeria" (2004), available at: $<$ http://www.foe.co.uk/> (last accessed 14 August 2007). See also paras 6-17 of the sworn affidavit of the plaintiff in Gbemre $v$ Shell, above at note 84, available at: $<$ http:// www.climatelaw.org/cases/case-documents/nigeria/ni-pleadings.doc $>$ (last accessed 9 December 2007). Ibid. 
ground. In western Europe, for example, 99 per cent of associated gas is used or re-injected. ${ }^{91}$ The Nigerian government's efforts to contain the problem have been suspect and this is largely due to institutional capture because of the heavy reliance of government on revenue from the industry. Under the Associated Gas Re-injection Act of 1979, which was the first piece of legislation to deal with gas flaring in Nigeria, oil companies were asked to submit schemes for the viable utilization of all associated gas and reinjection programmes. All companies were to stop flaring gas by 1 January 1984. A drastic penalty of forfeiture of all concessions was to be imposed for flaring after that date. However the government eased the provisions of the law before it could take full effect in 1984. The government enacted the Associated Gas Re-injection Act (Continued Flaring of Gas Regulations) 1984 and The Associated Gas Re-Injection (Amendment) Decree no 7 of 1985 which permit a company engaged in the production of oil and gas to continue to flare gas in a particular field or fields if a ministerial certificate is issued to that effect. It is unclear whether such certificates are issued in Nigeria because the issuance or non-issuance of such certificates is not made public and cannot be challenged by a private individual. ${ }^{92}$ Furthermore, the discharge in harmful quantities of any hazardous substance into the air or upon land and waters without lawful permission is criminalized under sections 21(1) and (2) of the Federal Environmental Protection Act. ${ }^{93}$ However the use of the phrase "lawful permission" gives the government the discretion to permit the flaring of gas by companies.

\section{Gbemre v Shell}

This case was brought by Jonah Gbemre on behalf of himself and the Iwhereken Community in Delta State, in the Niger Delta area of Nigeria against Shell Petroleum Development Company Nigeria Ltd, the NNPC and the Attorney General of the federation. The case was brought under the fundamental rights enforcement procedure in the Nigerian constitution, alleging violations of both constitutional provisions and the African Charter. The plaintiffs claimed that the oil exploration and production activities of Shell, which led to incessant gas flaring, had violated their rights to life and the dignity of the human person under sections 33(1) and $34(1)$ of the constitution and articles 4, 16 and 24 of the African Charter. The plaintiffs alleged that the continuous gas flaring by the company had led to poisoning and pollution of the environment which exposed the

91 Omoregbe "The legal framework for the production of petroleum in Nigeria", above at note 12 at 284 .

92 See for example Oronto Douglas $v$ Shell Petroleum Development Company Ltd and Ors (unreported suit no FHC/L/CS/573/93) where the plaintiff, among other things, sought a declaration that Shell Petroleum Development Company could not lawfully commission, carry out and operate liquefied natural gas projects without first complying with the Environmental Impact Assessment Decree no 86 of 1992 . The court struck out the suit on the ground that the plaintiff lacked the necessary standing. 
community to the risk of premature death, respiratory illnesses, asthma and cancer. They also alleged that the pollution had affected their crop production thereby adversely affecting their food security. They claimed that many of the natives had died and many more were suffering from various illnesses. The community was therefore left in a state of gross underdevelopment.

The defendants opposed the case on several grounds, including that those articles of the African Charter do not create enforceable rights under the Nigerian fundamental rights enforcement procedure. However they failed to follow up their arguments during the proceedings due to procedural issues. ${ }^{94}$ The judge therefore proceeded to judgment without any findings of fact, which rendered the judgment bereft of any in-depth legal analysis. In its judgment, the court held that the constitutionally protected rights include rights to a clean, poison-free, pollution-free environment and that the actions of Shell in continuing to flare gas in the course of its oil exploration and production activities in the plaintiffs' community violated their right to life and/or the dignity of the human person under the constitution and the African Charter. Even though there is no apparent justiciable right to a "clean poison-free, pollution-free and healthy environment" under the Nigerian constitution, the court relied on a cumulative use of constitutional provisions with the provisions of the African Charter (especially article 24) to recognize and apply a fundamental right to a "clean poison-free, pollution-free and healthy environment". ${ }^{95}$ This is in line with the decision of the African Commission in the SERAC case, though the Nigerian court did not refer to the case in its judgment. ${ }^{96}$ The implication of this decision is that there is a possibility of resorting to the African Charter for rights which are not available under national law.

The plaintiffs' counsel further argued that the provisions of the Associated Gas Re-injection Act (Continued Flaring of Gas Regulations) 1984 and The Associated Gas Re-Injection (Amendment) Decree no 7 of 1985 which allow for continuation of gas flaring are inconsistent with the right to life (which includes the right to a healthy environment) guaranteed under the constitution. The court agreed with this argument and held that legislation permitting flaring of gas in Nigeria, with or without permission, is inconsistent with the Nigerian constitution and, therefore, unconstitutional. The court therefore directed the Attorney General of the federation

94 Counsel to Shell and the NNPC had several times during the proceedings sought unsuccessfully to delay the action following which the court was constrained to foreclose further defence.

95 G Fortman "Adventurous judgments: a comparative exploration into human rights as a moral-political force in judicial law development" (2006) 2/2 Utrecht Law Review, available at: <http://www.utrechtlawreview.org/> (last accessed 29 August 2007).

96 The African Commission on Human Rights held in the SERAC $v$ Nigeria case (above at note 68) that the failure of the Nigerian government to prevent the escape of toxic waste from oil reserves violated the right to health (art 16) and the right to a clean environment (art 24) of the African Charter. The Nigerian government had argued that the rights are vague and incapable of legal enforcement. 
and the minister of justice to take steps to amend relevant legislations governing gas flaring to bring them in line with provisions on fundamental rights under the Nigerian constitution. The significance of this is that fundamental rights protection is held as an objective which other regulations must meet in order to be valid under the law. This clearly invalidates the discretion given by extant legislation to the government to permit gas flaring as it deems fit. The court consequently restrained the company from further gas flaring in the plaintiffs' community.

This case introduced a significant shift in the control of MNCs under Nigerian law as human rights provisions were relied on for the first time. It is also significant to note that the provisions employed were not only constitutional provisions, but also provisions in the African Charter, which is wider. Unlike the procedural limitations that have for example attended tort based claims, ${ }^{97}$ the human rights approach enabled the court to grant an injunction to protect rights considered to be fundamental and which should not be ignored on a balance of convenience test, as in the case of an injunction under tort law. Another significant point to note here is that the fundamental right enforcement procedure is much faster than other litigation procedures in Nigeria. This case took less than a year to conclude compared with other cases brought using other procedures which take an average of three years in the court of first instance. ${ }^{98}$

Furthermore, the decision also explicitly recognized the duty of non-state actors, ie corporations, vis-à-vis human rights, which signals the possibility of the horizontal application of human rights provisions to corporations in Nigeria.

\section{CONTROLLING MNCS UNDER HOST STATE LAW: POSSIBILITIES IN NIGERIA}

From the foregoing discussions, it is the opinion of this writer that, despite obvious gaps within the domestic context, there are opportunities for the control of MNCs which may be supported and complemented by regional and international arrangements. These opportunities are also considered as ways by which the law can robustly work with CSR to make the concept more meaningful.

\section{Maximizing the benefits of Gbemre $v$ Shell}

The decision in Gbemre $v$ Shell has thrown light on a possibility which has not received much attention in the Nigerian context. The decision has not only shown that the human rights approach is practical and realistic but that it also has some significant advantages over other approaches within

97 Some of these limitations were discussed in JG Frynas "Legal change in Africa: evidence from oil-related litigation in Nigeria” (1999) 43/2 Journal of African Law 121-50.

98 JG Frynas "Problems of access to courts in Nigeria: results of a survey of legal practitioners" (2001) 10 Social Legal Studies 397 at 410. 
the Nigerian context. As shown earlier, the approach would check government complicity and complacency in respect of abuse by MNCs. Secondly, it avoids the procedural drawbacks associated with other approaches. It is much faster, thereby making it more cost effective, and lastly it accommodates the application of supranational norms, such as the African Charter. The success of this approach largely depends on lawyers in Nigeria taking up the benefits it offers and judges' ability to appreciate the approach as demonstrated in Gbemre $v$ Shell. Furthermore, considering that many of the provisions implicating issues raised in the CSR discourse are contained in chapter II of the constitution and in view of the Supreme Court decision in AG Ondo $\mathcal{\sigma}$ Ors $v$ AG Federation $\mathcal{E}$ Ors (discussed earlier) ${ }^{99}$ that the provisions in the chapter could be made enforceable, there is a duty on the legislature to adopt a more proactive attitude to activate the constitutional provisions under chapter II.

\section{Reforming Nigerian corporate law and governance}

This article posits that there is a need to reconstruct the role and purpose of corporations under Nigerian company law and governance structure in order to make MNCs more responsive to issues raised in the CSR discourse and to make them more amenable to control. A step forward in this direction would be to move Nigerian corporate law and governance structure closer to the dominant model in the European Union, the social I stakeholder inclusive model of corporate governance. While it is acknowledged that the EU model has developed over time through many different legislative paths, including employment legislation, social security and central planning in the construction of the corporation as a social actor, this article suggests that some key elements of Nigerian company law could be modified as a first step in an attempt to reconstruct the purpose of the corporation in line with the social model.

The model currently followed in Nigeria, based on the Anglo-Saxon / US contractarian, private, shareholder-wealth-maximization model, has proved irrelevant in addressing the issues raised by the operations of MNCs. ${ }^{100}$ The model is not only problematic from other stakeholders' perspectives but also constrains the ability of MNCs to address conflicting demands made on them in consequence of their operations. Furthermore, the model ignores the local context in which MNCs operate and distances the corporation from society. While this article does not suggest doing away with the private structure of corporations, it advocates harnessing the potentials of the private structure for the public interest. Addressing other stakeholders' issues will not be possible without making reforms to

99 See note 76 above.

100 I have distinguished between the US model of the company and the prevalent model in the EU and how they play out in the Nigerian context in O Amao "Reconstructing the role of the corporation: multinational corporations as public actors in Nigeria" (2007) 29 Dublin University Law Journal 312. 
corporate law in a way that opens up corporations to other stakeholder issues. It is in the light of this that this article urges a shift in Nigerian corporate governance to the European Union's progressive, public and stakeholder-protection model. This article posits that such a shift would effectively reposition corporations within the context of their operations.

Directors' duties under the CAMA should be widened to include duties to other stakeholders. At present, under the CAMA, company directors owe duties only to the company (interpreted as its shareholders), and therefore have no legal responsibility or capacity to embark on any other duty apart from their duty to the company and its shareholders. ${ }^{101}$ The proposed change would allow the directors to take appropriate account of the interests of non-shareholding stakeholders. As a start, other stakeholders should be defined to include employees and people within the area of a company's operations who are directly affected by its activities. The new legislation on directors' duties in Britain is instructive in this regard. ${ }^{102}$

Furthermore directors' reports under the act should include reporting on companies' social and environmental performance. At present, the directors' report requirement under section 342 of the CAMA relates solely to the company's financial performance, while three additional heads of information must be included in the annual report. ${ }^{103}$

A further possibility is to amend the Code of Best Practices on Corporate Governance in Nigeria ${ }^{104}$ to include non-shareholder stakeholder issues. Presently the code only addresses three narrow areas of corporate governance, which include the board of directors, the shareholders and audit committee. ${ }^{105}$ The code could spell out minimum standards expected of corporations with regard to non-shareholding stakeholders. The voluntary nature of the code has rendered it largely ineffective since its adoption. It may therefore be necessary to create an enforcement / monitoring mechanism for its provisions.

It is further suggested that section 5 of the CAMA, which mandates foreign companies to be locally incorporated before they can carry on business in Nigeria, be expunged from the law as it is counterproductive. It only provides a stronger shield for parent companies of MNCs without being of any special advantage to the country.

101 See sec 279 of the CAMA. See also Orojo Company Law in Nigeria, above at note 37 at 295321. However, sec 38 of the CAMA, on powers of the company, allows the company to make donations except to a political party or political association.

102 See British Companies Act 2006.

103 See note 66 above.

104 See The Report of the Committee on Corporate Governance of Public Companies in Nigeria, April 2003, available at: <http://sec.gov.ng/pdf/Corperate\%20Goverance\% 20itd.pdf $>$ (last accessed 9 December 2007).

105 VO Nmehielle and ES Nwauche "External-internal standards in corporate governance in Nigeria" (The George Washington University Law School public law and legal theory working paper no 115,2004$)$. 


\section{CONCLUSION}

This article has explored the legal and institutional framework for the control of MNCs in Nigeria. It noted that, because of the colonial nature of the origin of the Nigerian law and the close linkage between MNCs and the colonial authorities, the pre-independence legislation in Nigeria was skewed in favour of MNCs. The colonial past has also influenced the post independence attempt to put some measures of control over MNCs. The gaps within the local context have left many issues that should be governed by law within the CSR domain. Despite this scenario, it is posited that there are opportunities under Nigerian law for the effective control of MNCs. The article has examined various areas of company law and human rights law and their implications for the control of MNCs. It went further to identify areas of Nigerian law which need reform in order to work effectively with issues raised by CSR. The article's position is that a domestic minimum standard is essential before other regional and international arrangements can be effective. 